International Journal of Biology, Pharmacy and Allied Sciences (IJBPAS)

'A Bridge Betueen Caboratory and QRendo'

WwW.iibpas.com

\title{
ISOLATION OF PLANT GROWTH PROMOTING RHIZOBACTERIA (PGPR) FROM SOIL: A REVIEW
}

\section{SONI T ${ }^{1}$, UPADHAYAY ${ }^{2}$, BHATTACHARYA $I^{2}$, ANDHARE ${ }^{2}$ AND MARCHAWALA $F^{2 *}$}

1: Student, MSc Biotechnology, Parul Institute of Applied Sciences, Parul University, Post Limda, Waghodia, Gujarat, 391760

2: Assistant Professor, Parul Institute of Applied Sciences, Parul University, Post Limda, Waghodia, Gujarat, 391760

*Corresponding Author: Farhat Marchawala; E Mail: farhat.marchawala82133@paruluniversity.ac.in;

Tel: +918758737462

Received $21^{\text {st }}$ Jan. 2021; Revised 23 ${ }^{\text {rd }}$ Feb. 2021; Accepted $24^{\text {th }}$ March 2021; Available online $1^{\text {st }}$ April 2021 https://doi.org/10.31032/IJBPAS/2021/10.4.1028

ABSTRACT

Plant Growth Promoting Rhizobacteria (PGPRs) are naturally soil-borne bacteria. These bacteria are useful as bio inoculant for increasing productivity of crops, grain quality, improve soil health and to conserve biodiversity. These bacteria are the group of bacteria, which are having ability to colonize roots of plants and helps them to increase their growth and the suppression of diseases by various mechanisms such as direct and indirect. They are also called as bio-fertilizers as they are useful to increase the productivity of plants. PGPRs have been functioning as interaction between plant and microorganisms as they both are helping each other. The interaction between plant and rhizobacteria is mutualism. Rhizobacteria are also use as biocontrol agents. Rhizobacteria, which are Resistance inducing and Antagonistic can be used as inoculants that would be useful for bio-control strategies to improve the cropping system.

Keywords: PGPR, Rhizobacteria, Biofertilizer, Biodiversity, Antagonistic \section{INTRODUCTION}

The narrow zone of soil which is known as rhizosphere is specifically influenced by root system [1]. The rhizosphere is the zone of soil which is surrounded by roots of plants where the chemistry and biology of soil were influenced by the roots of plants [2]. Rhizosphere having ability to stimulate microbial activity. The bacteria which are 
present in rhizospheric soil are responsible for plant growth are known as Plant Growth Promoting Rhizobacteria (PGPR) [3]. They are not only involved in plant growth but they also help in protecting environment and sustainable agriculture development [4]. Certain bacteria such as Pseudomonas, Bacillus, Azospirilium, Azatobacterand Rhizobium are reported for enhancing plant growth from last decades [5]. PGPR are helpful soil bacteria which help in plant growth via direct and indirect mechanism [6]. Increasing plant productivity is due to the symbiotic nitrogen fixation; solubilisation of phosphate, potassium; and other nutrients such a plant hormone [7].
The variations in environmental factors may cause variances in performance of PGPR that may affect on the growth of plant. By knowing how the rhizospheric bacteria exert their effects on plant we can achieve maximum growth promoting interactions between PGPR and nursery seedling [8]. Bacteria which are associated with plants are classified as beneficial, neutral and deleterious groups depends on their interaction with plants are used commercially and hold great importance for agriculture which is sustainable. Certain crops such as maize, potatoes, wheat, lentils, oat, tomatoes, barley,canola, pea and cucumber were observed as great application of these associations.

Table 1: PGPR microorganisms with their traits

\begin{tabular}{|c|c|c|}
\hline $\begin{array}{c}\text { NAME OF THE } \\
\text { MICROORGANISM }\end{array}$ & PGPR TRAIT & REFRENECE \\
\hline Acetobacter diazotropicus & Solubilization of phosphate & [9] \\
\hline Gluconacetobacter sp. & Solubilization of phosphate & [10] \\
\hline B. circulanscan & Potassium solubilizer & [11] \\
\hline Bacillus mucilaginosus & Potassium solubilizer & [12] \\
\hline Pseudomonas fluorescence & HCN producer & [13] \\
\hline Alcaligenes sp. & HCN producer & [14] \\
\hline Pseudomonas sp. & IAA production & [15] \\
\hline Bacillus sp. & Siderophores, Ammonia, HCN, Phosphate solubilizer & [16] \\
\hline Pseudomonas sp. & $\begin{array}{c}\text { IAA, Siderophore, HCN, P solubilizer, Heavy metal } \\
\text { chelation, Antibiotics }\end{array}$ & [17] \\
\hline
\end{tabular}

\section{PGPR traits:-}

\section{Phosphate solubilizers:-}

Certain strains of the genera such as Pseudomonas, Bacillus and Rhizobium are the most abundant phosphate solubilizers. The bacteria which are having ability of solubilizing inorganic phosphorus from insoluble compounds are called as Phosphate Solubilizing Bacteria (PSB). The production of organic acids is the main role of phosphate solubilisation. Certain bacterial strains such as Pseudomonas spp., Bacillus spp., Rhizobium spp., Micrococcus spp., Flavobacterium spp., Achronobacter spp., Erwinia spp. and Agrobacterium spp.were reported to ensure high crop yields by increasing the solubilization of phosphate [18]. 


\section{IAA producer:-}

Indole-3-Acetic Acid (IAA) is plant Phytohormone of class Auxin. It is capable to regulate the growth and developmental processes like cell division and elongation, apical dominance, response to light, gravity, tissue differentiation and pathogens. Synthesis of IAA is direct mechanism of PGPR related to plant growth. Mostly soil-borne bacteria and rhizobacteria having ability to produce IAA. The interactions between rhizobacteria and plants IAA play an important role. Certain species of bacteria such asAlcanigens, Pseudomonas, Bacillus, Sterptomyces, Azatobacter and Agrobacterium were reported as IAA producers [19].

\section{Siderophores producer:-}

In Greek, siderophores means "iron carrier". Siderophores are organic compounds with low molecular masses that are produced by plants and microorganism which are able to grow under low iron conditions. Some bacteria secrete ferric-ion specific ligands under iron-limiting conditions are known as siderophores. Siderophores are work as chelating agent and chelate the ferric iron from various habitats such as forestry area and water resources area to make it available for microbial cell. Siderophores have their potential role and applications in various areas of environmental research because of that siderophores have received much attention. Siderophores have ability to bind a variety of metal in addition to iron and they also have a wide range of chemicals and specific properties [20].

\section{Potassium solubilizer:-}

For growth and development of plant, Potassium is essential element. Shelf life of crops can be increased by potassium. Some organisms were reported to release the potassium in accessible form potassium (K) bearing minerals in soil such as Bacillus mucilaginosus, Bacillus circulans, Bacillus edaphicus, Acidothiobacillus ferrooxidans, Pseudomonas, Burkholderia etc. Potassium solubilizing bacteria (KSB) may be served as inoculants. KSB having ability of converting insoluble potassium in the soil into the soluble form of potassium so that plant can access. The most important role of KSB is to improve soil fertility and yield attributing characters. It is reported that the Indian soil contains good amount of potassium as secondary mineral [21].

\section{Nitrate Reduction:-}

This test is based on the detection of whether nitrite is present in the medium or not. Nitrate reducing bacteria having ability to use the enzyme nitrate reductase and reduce nitrate to nitrite. This test also detects the ability of microorganism to perform nitrification on nitrate and nitrite to produce nitrogen molecule [22]. 


\section{Ammonium production :-}

Ammonia is an important source of nitrogen which is required by plants which is present in air, soil and water. To promote the growth of plant, to improve seed and fruit production and for greater yield nitrogen is required. Ammonium is also essential for photosynthesis. To detectammonium production by PGPR's, the method described by Cappuccino and Sherman is used [23].

\section{Catalase Activity :-}

Catalase activity is one of the most important traits of bacteria as it is useful for bacteria to protect them against Hydrogen Peroxide which is a very dangerous compound for bacteria as well as for roots of plants. PGPR's having catalase activity can survive in the soil of rhizosphere and can promote plant growth indirectly. Certain microorganisms such as Listeria, Corynibacterium diptheriae, Burkholderia cepacian, Nocardia, Staphylococci and Micrococci are reported as catalase positive [24].

\section{Cynogenic Activity (HCN Production):-}

Cynogenic activity or $\mathrm{HCN}$ production by the rhizobacteria have been reported as having an important role in the biological control of pathogens. Certain bacterial species such as Alcaligenes, Aeromonas, Bacillus, Rhizobium and Pseudomonas were reported as having ability to produce Hydrogen Cyanide (HCN) [25].

\section{DISCUSSION}

Plant Growth Promoting Rhizobacteria (PGPR) are soil borne bacteria. They can be used as bio inoculants as they increase plant growth by different mechanism like direct and indirect. These bacteria are beneficial to plant for their growth and productivity. They are also useful as biofertilizers, which are having ability to enhance the productivity and growth of plant. It is reported that PGPR bacteria are useful for growth of plant by different parameters including Phosphate solubilization, IAA production, Siderophores production, Potassium solubilization, by reducing Nitrate, Ammonium production, Catalase activity and by Cynogenic activity.

\section{CONCLUSION}

PGPR are beneficial for plant growth promotion economically and environmentally. PGPR can also be used as biofertilizers for enhancing the growth and productivity of plant and it may also be used as bioinoculants as an efficient approach for replacement of chemical fertilizers and other growth promoting activity. This review specifies the formulations and advances of PGPR by identifying different characteristic of plant growth. Mostly isolated PGPR significantly expand plant height, root height and production of dry matter in various agriculture crops such as wheat, maize, 
tomato, potato, etc. It could be concluded that PGPR would enhanced the growth due to the production of IAA, siderophores production, ammonium production, potassium solubilisation, phosphate solubilisation and also due to the ability of to reduce nitrate.

\section{REFERENCES:}

[1]Lugtenberg, B., \& Kamilova, F. (2009).

Plant-growth-promoting rhizobacteria.

Annual review of microbiology, 63, 541-556.

[2]Schwyn, B. and Neilands, J. B. 1987. "Universal chemical assay for the detection and determination of siderophores". Analytical Biochemistry 160:47-56,

[3]Kloepper, J. W., Lifshitz, R..Zablotowicz, R. M.1989. "Free living bacterial inocula for enhancing crop productivity". Trends Biotechnology.7, $39-43$

[4]Okon, Y. and Labandera-Gonzalez, C. A. "Agronomic applications of Azospirillium. In improving Plant Productivity with Rhizosphere Bacteria" (eds Ryder, M. H., Stephens, P. M. and Bowen, G. D.), 1994. Commonwealth Scientific and Industrial Research Oraganization, Adelaide, Australia, pp. 274-278,

[5]Glick, B. R. 1995. "The enhancement of plant growth by free living bacteria".
Canadian Journal microbioll41, 109114 ,

[6]Glick, B. R. and Bashan, Y. 1997. "Genetic manipulation of plant growthpromoting bacteria to enhance biocontrol of phytopathogens". Biotechnol. Adv. Vol. 15, 353-378.

[7]Arshad, M. and Frankenberger, Jr. W. T. 1991. "Microbial production of plant hormones". Plant Soil, 133: 1-8.

[8]Bent, E., Tuzun, S., Chanway, C.P., Enebak, S. 2001." Alteration in plant growth and in root hormone levels of lodgepole pines inoculated with rhizobacteria" Can. J. microbial. 47:793800.

[9]Awasthi, R., Tewari, R., Nayyar, H. 2011. Synergy between plants and Psolubilizing microbes in soil: effects on growth and physiology of crops. Int. Res. J. Microbiol. 2, 484-503.

[10]Bard, M.A., Shafei, A. M., Sharaf ElDeen, S.H. 2006. The dissolution of Pbearing minerals by silicate dissolving bacteria and their effect on sorghum growth. Res. J. Agri. Biol. Sci. 2, 511.8

[11]Archana, D. S., Nandish, M.S., Savalgi, V.P., Alagawadi, A.R. 2012. Screening of potassium solubilizing bacteria for plant growth promotional activity. BIOINFOLET-AQuartely J. Life Sci. 9, 627-630. 
[12] Archana, D., Nandish, M., Savalgi, V., Alagawadi, A. 2013. Characterization of potassium solubilizing bacteria from rhizosphere soil. BIOINFOLETAQuartely J. Life Sci. 10, 248-257.

[13] Castric P.A. 1977. Glycine metabolism by Pseudomonas aeruginosa: hydrogen cyanide biosynthesis. J. Bacteriol. 130, 826-831.

[14] Castric K.F., Castric P.A. 1983. Method for rapid detection of cyanogenic bacteria. Appl. Environ. Microbiol. 45, 701-702.

[15] Karnwal, A. 2009. Production of Indol acetic acid by fluorescent Pseudomonas in the presence of L-Tryptophan and Rice root exudates. Journal of plant pathology. 91, 61-63.

[16] Klopper, J. W., Ryu, C. M., and Zhang, S. 2004. Induced systemic resistance and promotion of plant growth by Bacillus spp. Phytopathology 94, 1259-1266. Doi: 10.1094/PHYTO.2004.94.11.1259.

[17] Rajkumar and Freitas 2008. Effects of inoculation of plant growth-promoting bacteria on N1 uptake by Indian mustard. Bioresour. Technol. 99, 3491-3498. Doi: 10.1016/j.biortech.2007.07.046.

[18] Park, J. H., Bolan, N., Megharaj, M., \& Naidu, R. (2011). Isolation of phosphate solubilizing bacteria and their potential for lead immobilization in soil. Joural of hazardous materials, 185(2), 829-836.

[19] Brick, J. M., Bostock, R. M. Silverstone, S. E 1994. "Rapid in situ assay for IAA production by bacteria immobilized on nitrocellulose membrane”. Appl. Environmental Microbial 57:535-538.

[20] Bakker, P.A.H.M. et al. 1986. Neth. J. Plant Pathol., 92: 249-256.

[21] Adesemoye, A. O., Kloepper, J. W. 2009. Plant-microbes interactions in enhanced fertilizer-use efficiency. Appl. Microbial. Biotechnol. 85, 1-12.

[22] V. B. D. Skerman, 1967. A guide to the identification of the genera of the bacteria, The Williams \& Wilkins Co., Baltimore, MD, p.218-220.

[23] Noumavo, P. A., Kochoni, E., Didagbé, Y. O., Adjanohoun, A., Allagbé, M., Sikirou, R., \& Baba-Moussa, L. (2013). Effect of different plant growth promoting rhizobacteria on maize seed germination and seedling development. American Journal of Plant Sciences, 4(5), 1013.

[24] Aebi, H. (1984). [13] Catalase in vitro. Methods in enzymology, 105, 121-126.

[25] Glick, B. R. (2012). Plant growthpromoting bacteria: mechanisms and applications. Scientifica, 2012. 